Mirjana Marinković*

Filološki fakultet

Univerzitet u Beogradu
821.512.161.09-3 Памук О.

doi 10.18485/analiff.2015.27.2.3

\title{
ESEJI ORHANA PAMUKA
}

\begin{abstract}
Rad istražuje esejističko delo Orhana Pamuka koje je vrlo značajno za njegov književni identitet. Eseji ovog pisca nastajali su različitim povodima i obuhvataju niz tema iz ličnog života, njegove intelektualne, književne i umetničke preokupacije, kolumne i tekstove pisane različitim povodima. Rad se bazira na delima Druge boje. Eseji i jedna priča, Kofer moga oca, Istanbul. Uspomene i grad, Naivni i sentimentalni romansijer i Delovi pejzaža. I kao romansijer i kao esejista i kolumnista, Orhan Pamuk dokazuje teško nadmašivu intelektualnu snagu i superiornost i status jednog od vodećih pisaca našeg vremena.
\end{abstract}

Ključne reči: Orhan Pamuk, esej, književnost, umetnost, politika.

Ime turskog nobelovca Orhana Pamuka najčešće se vezuje za umetnost pisanja obimnih, slojevitih, postmodernističkih romana. Ta strana njegovog stvaralaštva predmet je sve brojnijih istraživanja u svetu, raznovrsnih po tematici i dubini. Sam Pamuk sebe identifikuje kao romanopisca po vokaciji koji se već tri decenije uspešno bavi isključivo tim poslom. Stoga jedan aspekt njegovog književnog rada neopravdano ostaje pomalo u senci romansijerstva, a to je njegovo esejističko delo.

Orhan Pamuk je kod nas poznat kao esejista od objavljivanja njegove memoarske proze Istanbul. Uspomene i grad 2006. godine (Pamuk: 2006). U više prikaza i osvrta na tu knjigu, koja se kod nas pojavila neposredno posle dodele Nobelove nagrade, retko se upotrebljavala reč esej ili esejista, iako je to upravo knjiga koja obuhvata specifične tekstove, po stilu i tematici najbliže esejima, posvećene Pamukovom voljenom gradu, uspomenama iz detinjstva i prve mladosti. Često je kvalifikovana kao „roman”, „klasični bedeker”, mada nije ni roman ni bedeker. Reč je, zapravo,

Filološki fakultet, Studentski trg 3,11000 Beograd, mirjana.marinkovic65@ gmail.com 
o žanrovski teško odredivoj esejističkoj prozi koja luta između ličnih uspomena, gradskih pejzaža, literature i razmišljanja o onome što grad čini gradom i što ga smešta u samo središte piščevog života i poimanja sveta. Najlepšu ocenu ovog Pamukovog dela dao je književnik Mirko Magarašević koji piše: „, U slučaju Pamukove, tečno pisane knjige Istanbul, reč je o veoma uspeloj, izrazito ispovednoj, autobiografskoj vrsti dela koje ima dinamični šarm jedinstvenog doživljajnog i asocijativnog toka, počev od detinjstva do uspešne ostvarenosti u piščevoj zrelosti”, i s pravom napominje da se stil „odlikuje misaonom elegancijom, lakoćom neposrednosti, prisnim sećanjima koja su uverljiva i, što je od posebnog značaja, odlikuje se osobitim tonovima meditativne sete i emocionalnim uzmicanjima kakva, ako ih tražimo, nećemo ih drugde naći jer i nisu odličja naše domaće autobiografske literature (Магарашевић, 2012: 201).“

Istanbul, međutim, nije prva knjiga ogleda Orhana Pamuka koji se često i rado odaziva pozivima raznih listova i časopisa koji od njega traže tekstove na određenu temu. Prva knjiga njegovih eseja, nastalih tokom osamdesetih i devedesetih godina prošlog veka, objavljena je pod naslovom Druge boje. Odabrani spisi i jedna pripovetka (Öteki Renkler. Seçme Yazılar ve Bir Hikâye) 1999. godine u Turskoj. Druga knjiga eseja nazvana Kofer moga oca (Babamın Bavulu) pojavila se u Turskoj 2007. godine, neposredno posle dodele Nobelove nagrade i Pamukove istoimene besede pred članovima Švedske akademije. U njoj su zastupljeni eseji Kofer moga oca, tj. beseda prilikom uručenja Nobelove nagrade, ogled Implicitni autor i tekst $U$ Karsu i u Frankfurtu. Poslednji je zapravo Pamukovo obraćanje književnoj publici u Frankfurtu 2005. godine. Treća i najnovija esejistička knjiga Orhana Pamuka pod naslovom Delovi pejzaža (Manzaradan Parçalar) izašla je iz štampe 2010. godine i predstavlja svojevrstan dodatak knjizi Druge boje. Srpsko izdanje Pamukovih eseja pod naslovom Druge boje. Eseji i jedna priča (Pamuk, 2011) predstavlja kolaž odabranih tekstova iz gore navedenih prethodno štampanih esejističkih dela u dogovoru sa samim autorom.

\section{O životu}

Pripovetka zastupljena u prvoj knjizi Druge boje nosi naslov Gledanje kroz prozor (Pamuk, 1999: 21-41). Nagovestila je ono u čemu će čitaoci 
imati priliku da uživaju nekoliko godina kasnije - a to je memoarska proza Istanbul, pretežno satkana od ličnih uspomena i porodičnog iskustva. Tekstovi knjiga Druge boje i Delovi pejzaža podeljeni su u nekoliko tematskih grupa, koje su zapravo tematska polja kojima je Pamuk zaokupljen i kao čovek i kao pisac. To su život, Istanbul, pisci i knjige, knjige koje je Pamuk sam napisao, umetnost, politika. Prva grupa eseja nazvana je jednostavno Život. Sadrži crtice iz piščevog ličnog svakodnevnog života, beleške o najobičnijim, ponekad i trivijalnim temama. Na primer - tekst posvećen Pamukovom osećanju déjà vu, $\mathrm{tj}$. da je ranije već bio na određenom mestu. Karakterističan je i esej Kako možete da spavate dok stvari govore, u kome se autor ne stidi da progovori o onim čudnim, mračnim, nedokučivim mislima koje svi često imamo i o kojima ne govorimo.

„Ali nikada nećete reći da razmišljate o takvim stvarima.

I ja tako činim. Ne govorim nikome.

Da prazne flaše ispred vrata nisu u skladu jedna sa drugom i sa svetom. Da je činjenica da su vrata ni sasvim otvorena ni sasvim zatvorena, jedan izvor nade.

Da motivi puževa na prekrivaču za fotelje do jutra govore: 'Uvijamo se i sve se više uvijamo, ali to niko ne primećuje.'

Da negde u blizini, sedam santima pod mojim nogama ili u plafonu, neke čudne larve polako nagrizaju beton i čelik, baš kao crvi drvo.

Da će se makaze na stolu odjednom pokrenuti i početi da seku onoga ko im naiđe kao da same tako žele i hoće, ali da krvava tragedija neće trajati duže od petnaest minuta.

Da telefon sâm razgovara s drugim telefonom i da je zato tih.

Sve ovo ni ja nikome ne govorim. Najpre me je činilo uznemirenim i nervoznim to što nisam mogao ni sa kim da podelim ove očigledne činjenice. Niko o tome ne priča, a ako ne priča, možda se samo meni otkrivaju te istine. Odgovornost za to nije samo teret. Čovek pomišlja i zašto se njemu otkrivaju tajne te značajne dimenzije stvarnosti. Zašto mi ova pepeljara kaže da je razbijena i nesrećna? Zašto je žalostan ovaj ključ na vratima (Pamuk, 2011: 32)?"“

U ciklusu eseja pod naslovom Život, Pamuk dosta prostora posvećuje svojoj kćerkici Ruji. U vreme pisanja tih tekstova Ruja je bila sasvim mala, a njen otac je opisivao neke tipične zajedničke trenutke koje su iskusili svi roditelji, ali ih nisu zabeležili. Tih nekoliko kratkih beleški 
otkrivaju našeg pisca kao čoveka zaljubljenog u onu običnu, malu ljudsku sreću koji se čak i pita „da li je sramota biti srećan?”

„Da li je sramota biti srećan? Često sam tako razmišljao. I sada često tako razmišljam. Čak ponekad kažem da su oni koji mogu da budu srećni loši ljudi i da su glupaci. Ali ponekad biva da mislim i na ovaj način: ne, nije sramota biti srećan, to je mudrost (Pamuk, 2011: 40).“

Iz iste esejističke zbirke su i eseji Moj otac, Berberi, Moji prvi susreti sa Amerikancima, Strepnja od zemljotresa u Istanbulu i drugi (Pamuk, 2011: 20-23; 297-299; 91-99).

Porodica, bez svake sumnje, zauzima jedno od najvažnijih mesta u Pamukovom životu. Njegove knjige većinom obiluju autobiografskim elementima koje nije teško nazreti čak i u njegovim istorijskim romanima. Tekst Moj otac (Pamuk, 2011: 20-23), međutim, eksplicitno razotkriva piščev odnos prema ocu Gunduzu Pamuku, koji je i sam bio zanimljiva i slojevita ličnost - pesnik, boem, zanesenjak, prevodilac Valerijevih stihova na turski jezik, netipičan otac koji nije bio autoritaran i hladan stub porodice, već lepršav, pomalo neodgovoran intelektualac ,s glavom u oblacima", kako je njegov sin zapisao. Očeva duga odsustvovanja dok je Orhan Pamuk bio sasvim mali trajno su se urezala u piščevu svest, a svoj književni izraz našla su i u romanu Zovem se Crveno i u knjizi Istanbul.

Kad je reč o ocu, nije nam promakla jedna „sitnica“ u eseju Moj otac. Naime, otac Gunduz Pamuk se jednom prilikom našao u velikom društvu u kome je bio i predsednik Republike Erdal Ineni. Kada se reč povela o turskoj književnosti, Gunduz Pamuk je postavio pitanje: „Zašto nemamo svetski poznatog pisca?“(podvukla M.M.)

„Erdal Ineni (očev drug iz detinjstva i sa Tehničkog univerziteta), koga sam video posle mnogo godina na otvaranju jedne izložbe, ispričao mi je smešeći se da je moj dvadesetogodišnji otac na jednoj porodičnoj večeri u palati Čankaja, na kojoj je bio gost, kada je Ismet-paša razgovor skrenuo ka književnosti, postavio pitanje: 'Zašto nemamo svetski poznatog pisca? ' Deset godina od kada su moje knjige počele da se objavljuju, otac mi je, pomalo se stideći, dao jedan mali kofer. Odlično znam zašto sam bio uznemiren zbog svezaka uspomena, pesama, književnih tekstova i beleški koji su iz njega ispadali - želimo da nam otac bude kakav mi želimo, a ne kakav jeste (Pamuk, 2011: 22).“

Sudbina je htela da upravo njegov sin postane turski ,svetski poznat pisac", za šta dosta zasluga, u prvom redu, za podršku i ohrabrenje na 
samom početku bavljenja književnošću, pripadaju upravo ocu Gunduzu Pamuku.

U ovom ciklusu ne možemo zaobići ni dva vrlo snažna teksta posvećena zemljotresu u Istanbulu i strahu od njega sa kojim se već dugo živi u tom gradu - Zemljotres, Strepnja od zemljotresa u Istanbulu. Moramo napomenuti da to nisu obične beleške o utiscima posle zemljotresa ili o strepnji sa kojom se u Istanbulu odlazi na počinak. To su moćne slike oplemenjene razmišljanjem, istraživanjem teme, analizom turskog društva, pronicanjem u nedokučive niti mentaliteta i ljudske prirode. Stranice koje je Orhan Pamuk posvetio razornom zemljotresu koji je pogodio Istanbul 1999. godine nisu samo svedočanstvo o prirodnoj katastrof $i$, već i spisateljskog majstorstva i umeća da u reč pretoči slike nesreće, nemoći i krhkosti ljudskog bića.

„Bilo je dosta ljudi koji su poput nas zbunjeno tumarli ulicama, i mi smo zajedno sa njima koračali između srušenih i uništenih zgrada od kojih nije ostao kamen na kamenu, automobila zarobljenih pod ruševinama, između popadalih električnih stubova, zidova i minareta, stajući na komade betona, krhotine stakla i električne i telefonske žice što su obavijale ulice. Videli smo šatore razapete po dvorištima gimnazija, parkićima i praznim parcelama. Videli smo ljude koji se zbunjeno raspituju za adresu, traže izgubljene bližnje, optužuju odgovorne za nesreću, ljude koji se međusobno svađaju oko mesta za postavljanje šatora. Ulicama su prolazila vozila koja su povremeno delila konzerve ili mleko u tetrapaku, kamioni puni vojnika, ili dizalice i bageri pri čemu su dizali prašinu od srušenih zgrada nataloženu u kaldrmi. Kao što biva među decom dobrano zanetom igrom koja su zaboravila na pravila realnog sveta, ljudi su na ulicama odmah počinjali neformalno i bez pravila međusobno da razgovaraju. Ne samo oni što su pitali za adresu, tražili svoje nestale, oni što su se žalili na državu i građevinske preduzimače, nego ožalošćeni zbog poginulih i umirućih odmah su vam i ne upitani počinjali da pričaju svoje priče. Katastrofa je svima ulivala osećanje da je svet u suštini postao neko sasvim drugo mesto. Kao da su najskrivenija i najsvirepija pravila života izbila na površinu poput stvari u onim kućama iz kojih su zjapili srušeni i ispreturani zidovi.

Dugo sam posmatrao stvari u nakrivljenim, napola srušenim kućama sletelih fasada, koje su se poput kućice-igračke naslonile na susednu zgra$\mathrm{du}$, kojima su vrhovi udarili u naspramnu građevinu. Mašinski tepisi što 
vise po uglovima poput zastava iskačenih u danu bez vetra, ormani kojima je polovina odletela, a polovina ostala, pohabani stočići - neizbežni komadi nameštaja u salonima, divani, fotelje, jastuci izbledeli od dima i prašine koja se na njih slegla, prevrnuti televizor, potpuno cele saksije i cveće na balkonu iako je cela kuća srušena, suncobrani izuvijani poput gume, usisivači sa crevima isturenim u prazno, bicikli nabijeni u ćoškove, sve one raznobojne košulje, koje se vide kroz otvorena vrata ormana, bade mantili okačeni na zatvorena vrata, sakoi... Zavese od tila koje su se ljuljale lagano se njišući na prijatnom vetru kao da se ništa nije dogodilo, zajedno sa celokupnim enterijerom te kuće koji se nisam mogao uzdržati da ne gledam, navodili su nas da osetimo koliko je ljudski život krhak i prijemčiv za zlo. Činili su da slutimo koliko nam životi većinom zavise od odluka ljudi koje potcenjujemo i o kojima loše govorimo. Svi oni užasni preduzimači na koje se godinama žalimo, opštine ogrezle u korupciji, građevinci koji ne poštuju propise i političari lažovi, nastali su među nama, potekli su od nas i naše jadikovke nas nisu mogle spasti njihove pokvarenosti (Pamuk, 2011: 86).“

\section{O Istanbulu}

Orhan Pamuk je poput mnogih svetskih pisaca nezamisliv bez rodnog grada, bez Istanbula. U turskoj književnosti nema pisca koji je na tako bravurozan način iskazao omaž gradu koji ga je stvorio i koji ga prati kao sudbina. Našim čitaocima je to postalo jasno sa knjigom Istanbul. Istanbul se za Orhana Pamuka ne sastoji samo od slika, ulica, građevina i pejzaža. On je mnogo više od toga. Doživljaj grada, koji „,nema centra izvan nas samih", čine i uspomene i pročitane knjige i utisci zapadnih pisaca i sopstveni životni put i identitet uslovljen njegovim duhom i atmosferom. Pamuk ne bi bio Pamuk kada govoreći o najobičnijim stvarima istanbulskog života ne bi dotakao univerzalne i krupne životne teme. „Istorija Istanbula je istorija požara i rušenja”, setno je primetio. Šta je ono što čini eseje posvećene Istanbulu neodoljivo privlačnim? Nesumnjivo da njihova magičnost proističe iz elegantnog spajanja prošlosti i sadašnjosti, piščeve načitanost koja naprosto vrca, sjajne erudicije i oštrine zapažanja pred kojom se ništa ne može sakriti. Orhan Pamuk je pisac surovo iskren i pošten, nepotkupljiv i nemilosrdan u opažanjima pa makar ona bila na štetu njegovih bližnjih, porodice, pa i njega lično. 
„Gradovi imaju dvojako lice. Građevine, spomenici, ulice i pejzaži koje će videti svaki turista, svaki stranac koji tek dođe u grad čine spoljno lice jednog grada. Ali i sobe u kojima ležemo i budimo se, učionice u kojima slušamo predavanja, hodnici, bioskopi imaju svoj intimni izgled koji se sastoji od posebnih uspomena, mirisa, svetla i boja. To možemo nazvati unutrašnjim licem gradova. Ono što je mnogo više od sličnosti koje spoljno lice nekog grada pokazuje od kvarta do kvarta, stvarni duh grada, ono što svi više čuvaju u svojim uspomenama, jesu to unutrašnje lice grada koje rušenja mnogo više odnose (Pamuk, 2011: 70).“

U esejima posvećenim Istanbulu, možda i najboljim koje je do sada napisao, Orhan Pamuk razvija jedan specifičan gradski senzibilitet. Ljubav prema Istanbulu duguje koliko lepoti njegovog lica i bogatstvu njegove istorije, toliko i knjigama i piscima koji su ga pripremili, kako kaže, za viziju Istanbula, za ono što će taj grad zauvek značiti u njegovom životu i književnom delu. Nišantaš, kvart u kome je odrastao, nije samo prestižna istanbulska četvrt. U intervjuu pod naslovom Poticati sa Nišantaša (Pamuk, 2010: 148-151) Orhan Pamuk govori o četiri razdoblja u životu ovog dela grada - vremenu od sredine do kraja 19. veka u kome je to bio deo ispunjen drvenim konacima paša koji su mahom nestali u požarima. Drugi period je bio vreme od kraja 19. do tridesetih godina 20 . veka, vreme zidanja kamenih građevina. Treće razdoblje nazvao je zlatnim dobom Nišantaša - vreme od 30-ih do 70-ih godina 20. veka kada je najveći deo istanbulske najviše klase živeo u Nišantašu. U poslednjem dobu Nišantaša od sredine 70-ih do 90-ih godina istanbulski bogataši napustili su Nišantaš, birajući delove pored Bosfora na azijskoj strani smatrajući ih privlačnijim i bezbednijim. Da li ovde pomalo podseća na Momu Kapora koji je svojevrstan hroničar beogradskog života? I druge njegove crtice iz Istanbula uveravaju koliko je duboko osećao damare života u njemu i koliko ga je sagledavao u svoj njegovoj punoći i višeznačnosti.

\section{O knjigama}

Pamukova opsesija u pravom smislu te reči nesumnjivo su pisci i knjige. Čitav niz eseja posvetio je pisanju i čitanju, velikanima svetske književnosti, piscima na koje se ugledao, kojima se divio i od kojih je učio. U nekoliko navrata Orhan Pamuk je pisao predgovore za turska izdanja 
pojedinih kapitalnih dela svetske književnosti. U napisima posvećenim književnosti on je posebno nadahnut i lucidan, što je i razumljivo.

Zadivljuju ozbiljnost i posvećenost koju ovaj pisac oseća prema literaturi. U njihovoj osnovi je snažna potreba za drugim svetom koji književnost nudi, za samoćom i dijalogom sa svetom književnog dela. „Nositi knjigu u džepu ili u tašni znači nositi u njima drugi svet koji će vas usrećiti, naročito u nesrećna vremena. Knjiga koju čitam sa zadovoljstvom za mene je uvek bila izvor utehe koji mi je ulivao snagu u napetim danima moje mladosti, na školskim časovima na kojima su mi oči suzile od zevanja ili na dosadnim sastancima na koje sam išao iz osećanja obaveze da se ne bih obrukao. Da nabrojim ono što čitanje čini izvorom sreće koji sam sam izabrao, a ne nužnost nametnutu obrazovanjem i poslom.

1. Uticaj drugog sveta koji sam ranije pomenuo. To se zove i čitanjem radi 'bekstva'. Dobro je na neko vreme naći utočište u drugom svetu, pa makar i imaginarnom, i pobeći od nesreće običnog sveta.

2. Čitanje je između moje šesnaeste i dvadeset šeste godine bilo deo ličnog samoostvarivanja i svesnog duhovnog oblikovanja... Znanjima koja sam sticao iz pročitanog skicirao bih putanju ličnosti kakva sam želeo da budem (Pamuk, 2011: 106)...”

$\mathrm{U}$ tekstu jednog predavanja studentima Univerziteta Kolumbija u SAD, na kome Orhan Pamuk drži kurs kreativnog pisanja, on ističe da „volimo da čitamo romane upravo iz sledećeg razloga: da bismo mešali imaginarno sa stvarnim. Ono što osećamo u tom momentu - u smislu kao što sam predložio na ovim predavanjima - jeste želja da budemo i ,naivni” i „sentimentalni” u isto vreme (Pamuk, 2010a: 44).” „Pravo zadovoljstvo čitanja romana počinje sposobnošću da vidimo svet, ali ne izvana, već očima onih koji žive u tom svetu (Pamuk, 2010a: 11).”

\section{O drugim piscima}

Pamukovi eseji posvećeni drugim piscima i književnim delima prava su poslastica za književne sladokusce. Ono što očarava jeste ogromno poštovanje koje gaji prema književnim velikanima, strasno, duboko, gotovo samorazarajuće iščitavanje knjiga. Ti eseji su u jezičkom i intelektualnom pogledu pravi vrhunci Pamukove esejističke proze. 
Tekstovi o piscima i knjigama nastajali su u različitim prilikama i u svakom od njih moguće je otkriti Pamuka kao strasnog čitaoca i zaljubljenika u roman, kao vrhunsku formu zapadne umetnosti. Ti ogledi ukazuju na ono što Pamuk najviše ceni u književnosti i na pisce, koji po njegovom mišljenju, zaslužuju najviše pažnje.

Pamuk je u različitim prilikama iznosio stav da su Braća Karamazovi ruskog klasika Fjodora Dostojevskog najveći roman prethodnog milenijuma. Dostojevski je pisac o kome je Pamuk pisao u nekoliko navrata i koga je smatrao svojim književnim uzorom. Između Turske i Rusije i Pamuka i Dostojevskog moguće je pronaći više podudarnosti, koje su možda presudile da Dostojevski već u najranijoj mladosti postane Pamukov književni ideal (Marinković, 2011: 167-173).

Među ogledima o piscima i knjigama ističu se oni posvećeni romanesknom delu Tomasa Bernharda, kontroverznog i nekonvencionalnog austrijskog književnika sklonog izrugivanju normama građanskog društva. Evo jednog odlomka:

„U čemu je bila tajna? Šta je predstavljalo to što mi je dolazilo kao isceljenje što sam u danima depresije više čitao Bernharda? Možda neka vrsta osećanja odustajanja, mudro nagoveštena etika da se od života ne očekuje suviše... A možda ne i etika. Laka ljutnja koja navodi da se oseti da je najzdravije da čovek ostane privržen sebi, svojim navikama i besovima. U Bernhardovim redovima ima shvatanja da je najveći idiotizam fantazirati o životu, odustati od svojih žudnji i navika... sreće u obrušavanju na tuđe gluparije i budalaštine... saznanja da na kraju ne preostaje ništa izvan onog što smo učinili iz strasti i opsesija..

Ali znam da su jalovi i svi ti pokušaji formulisanja. Ne samo zato što je teško da u Bernhardovim knjigama pronađem stranice i redove kojima bih potkrepio ovo što govorim... Zato što u svakom novom čitanju shvatam da su njegove knjige nedostupne za tu vrstu uprošćavanja... Možda je jedina stvar koju mogu da kažem a da ne zapadnem u tu nedoumicu: ono što me je činilo srećnim dok sam čitao Bernhardove redove nisu viđenja, moral, pozicija i ostalo što njegove knjige bravurozno nagoveštavaju... Biti u tim redovima, na tim stranicama je ono što donosi olakšanje. Sreću mi samo po sebi nije donosilo ono na šta ukazuje tekst, već što sam se nalazio u silini redova, u razuzdanom gnevu.

Svi veliki pisci nas čine srećnim ne onim što jesu već onim što nisu rekli (Pamuk, 2011: 151).“ 


\section{O sopstvenim knjigama}

Jednu grupu eseja čine napisi o Pamukovim knjigama. Nose simboličan naslov Moje knjige su moj život. Iz piščevih tekstova posvećenih idejama koje su pratile rad na sopstvenim knjigama saznajemo i za jednu od stalnih opsesija turskog nobelovca - a to je nasušna potreba za samoćom i zatvaranjem u jednu sobu u kojoj će nesmetano moći da mašta i da piše. Sva druga dešavanja, obični svakodnevni događaji i iskustva padaju pred Pamukovom žudnjom za samoćom i zatvaranjem u sopstveni svet u kome postavlja sopstvena pravila. Na primer, u eseju posvećenom pisanju Crne knjige to dolazi do punog izražaja.

Taj esej je posebno zanimljiv zato što se u njemu Pamuk u potpunosti razotkriva i bez imalo ustezanja iznosi na videlo svoja stanja i kolebanja dok je pisao tu knjigu, koja je proglašena njegovim najkontroverznijim delom. I u drugim tekstovima Pamuk je pisao o tehnici sklapanja priče, o elementima tog složenog mozaika koji se na kraju sastavlja u jedno pitko književno štivo. Međutim, u eseju Crna knjiga: deset godina posle, Orhan Pamuk ubedljivo pokazuje u kojoj meri se „preselio“ $\mathrm{u}$ realnost knjige koju je pisao:

„Ali ni u kutku u koji sam se zatvorio knjigu nikako nisam mogao da završim. (Crnu knjigu sam napisao za oko pet godina.) Pored zadovoljstva u pisanju i samoći, činjenica da što sam više pisao u tom zapećku kraj knjizi nikako nije dolazio, počela je da me s nekih čudnim osećanjem depresije i straha polako pretvara u mog junaka Galipa. Kao i Galip koji nije mogao da nađe ženu što ju je više tražio, koji se u međuvremenu susretao s drugim stvarima na koje nikako nije računao i koji, osećajući da je nesrećan i da je pretrpeo gubitak, nije mogao u potpunosti da uživa u onim čudesima, podzemnim tunelima, Turkan Šoraj i njoj sličnima i svim onim kolumnama kojr je čitao usled osećanja gubitka i nesreće - i ja sam do tančina u sebi osećao zadovoljstvo u toj knjizi koja me je usrećivala što se više razvijala, ali nikako nisam uspevao da je slavim sa osećanjem trijumfa. Posle nekog vremena sam se na mestu gde sam pisao osetio potpuno samim, baš kao i Galip. Prestao sam da se svakodnevno brijem i da vodim računa o izgledu. Sećam se da sam jedne večeri išao kao avet zabačenim ulicama Erenkoja, u groznim starim patikama, s kačketom na glavi, u mantilu sa pootpadalim dugmadima i sa užasnom kesom u ruci. Ulazio bih nasumice u neki restoran ili bife, dušmanski gledao unutra i utoljavao 
glad. Sećam se da mi je otac, koji me je posećivao jednom u dve nedelje i izvodio na ručak, davao savete zabrinut zbog pršljavštine i zapuštenosti stana u kom sam živeo, mog ruiniranog izgleda i činjenice da knjigu nikako nisam završavao (Pamuk, 2011: 228).“

\section{O umetnosti}

Sledeća celina u Pamukovom esejističkom opusu posvećena je umetnosti. Orhan Pamuk je, kao što je mnogima poznato, maštao o tome da postane slikar. Studirao je arhitekturu koja je trebalo da pomiri porodični inženjerski duh i umetnost. Na kraju, postao je romanopisac koji često pribegava vizuelnim umetnostima i njihovom rečniku. Konačno, boje kod njega igraju vidnu ulogu i zato ne treba da čudi zašto se jedna od njegovih esejističkih knjiga naziva Druge boje i zašto se boje sreću kao lajtmotiv nekih njegovih romana (Zovem se Crveno, Crna knjiga). U razmišljanjima o razlozima svetskog uspeha Orhana Pamuka čovek ne može da se otme utisku da, kako u njegovoj ličnosti tako i u njegovom delu, Istok i Zapad čine prirodnu, organsku celinu, da njegovo, uslovno rečeno, istočnjačko poreklo i proevropsko obrazovanje čine jedan prefinjen spoj koji sugeriše da je svet u kome živimo jedinstvo razlika, jedinstvo iskustava i estetika, ali da je sve delo jednog jedinstvenog i svuda jednakog ljudskog bića.

Kao i u ogledima posvećenim književnosti, i spisi o umetnosti rezultat su izuzetne obaveštenosti i poznavanja materije. Ako tome dodamo oštro oko i Pamukov odnegovani umetnički ukus, dobili smo sjajne eseje koji prevazilaze povod zbog kojih su nastali. Odličan primer takvog teksta je onaj pod naslovom Belini i Istok koji je Orhan Pamuk napisao povodom otvaranja izložbe Belinijevih slika u Nacionalnoj galeriji u Londonu. „Zbog zabrane slikanja u islamu, naročito zbog straha od slikanja lica i neznanja, osmanski minijaturisti nisu pravili i nisu znali da prave tako realistične portrete sultana. Ali ta uzdržanost kad su u pitanju individualne osobine čoveka nije bila ograničena samo na slikarstvo. I osmanski istoričari koji su mnogo pisali o vojnim i političkim događajima tog vremena, iako u tome nije bilo verskih zabrana, nisu razmatrali sultanove lične osobine, karakter, dubine duha, i o njima nisu pisali. U prvoj polovini 20. veka, kada je osnovana moderna Republika Turska i uz pokret evropeizacije nastala moderna turska nacija, nacionalistički pesnik Jahja Kemal, koji je bio svestan svih tih mučnih književnih i kulturnih problema, godinama živeo u 
Parizu i izbliza poznavao zapadnu književnost i slikarstvo, tužno je rekao: 'Da smo imali slikarstvo i prozu, bili bismo sasvim drugi narod!' Ono na šta je mislio nije bilo samo da se lepota izgubljene prošlosti uhvati, utvrdi i dokumentuje slikama i pisanjem. C̆ak i kad nije bilo tog nedostatka, dakle kad je bio pred 'realističkom' slikom sultana Mehmeda Osvajača koju je uradio Belini, želeo je da ruka koja ju je izradila i osećajnost koja je pokrenula tu ruku budu 'nacionalne', a možda i da se koristi tradicionalnim načinima izražavanja i da ih razvija. Iz tih reči naslućuje se duboko nezadovoljstvo, nezadovoljstvo jednog muslimanskog pisca 'manjkavostima' sopstvene kulture. U njima do izražaja dolazi san o lakom preuzimanju i primeni privlačnih umetničkih proizvoda jedne sasvim drugačije kulture i civilizacije, ali bez menjanja sopstvenog duha. Neki plodovi tog naivnog sna koji privlače pažnju stručno su obrađeni na izložbi Belini i Istok (Pamuk, 2011: 282-283)...“

Čitajući ove Pamukove tekstove čovek ne može da se otme utisku da su Istok i Zapad neopravdano i nezasluženo udaljeni i ophrvani međusobnim nepoznavanjem i nerazumevanjem, jer su koreni istočnjačkog, uslovno rečeno, zaostajanja i zapadne superiornosti mnogo kompleksniji i dublji i ne daju se svoditi na istorijske klišee.

Esej Selimija potvrđuje Pamukovu upućenost u umetnost i arhitekturu , ali i sposobnost da jedan biser osmanske arhitekture posmatra kao proizvod osmanskog shvatanja vlasti i pogleda na svet. „Velike džamije iz prvih razdoblja Osmanske imperije, baš kao Sinanova dela iz mladosti, zahvataju velike površine sa mnogo malih kupola i polukupola, a lepota građevina proisticala je iz harmonije između velike kupole u sredini koja se nije dovoljno izdvajala od ostalih, polukupola koje su je podržavale, nosećih kula i potpornih zidova. A kod džamije Selimije, koju je Sinan nazvao svojim 'majstorskim delom', osnovna ideja je da samo jedna velika kupola vlada celim zdanjem. Kad mi je bilo dvadeset godina, ja sam kao student arhitekture zajedno sa drugovima uspostavljao vezu između ideje o 'jednoj kupoli' i ideje o nemilosrdnoj političkoj i ekonomskoj centralizaciji osmanske države. A Sinan u knjizi, koju je po njegovom diktatu napisao pesnik Sai, njegov prijatelj, kaže da mu je na umu bila kupola Aja Sofije u Istanbulu.

Ta misao o centričnosti i simetriji naglašena je najvišim minaretima $\mathrm{u}$ islamskom svetu podignutim na četiri strane kupole. Tri odvojena 
stepeništa na dva minareta, koja se nezavisno jedno od drugog i bez ukrštanja penju na tri različite šerefe, izgledaju kao sažetak beskrajne igre geometrije i simetrije na građevini. Ali pošto oseti svu tu brigu za raskoš i simetriju, kad uđe u džamiju, čovek se zbuni pred jednostavnošću i čistotom unutrašnjosti. Ta zbunjenost navodi posetioca da oseti tajnu arhitekture osmanlijske džamije - neposrednost veze sa Bogom, jednostavnost unutrašnjosti koja uliva osećanje bliskosti između Alaha i roba, zajedno s pretencioznim monumentalnim spoljnim izgledom koji simbolizuje moć i bogatstvo Osmanske imperije i želju sultana da ostave trag. Kao i kod svih velikih osmanlijskih džamija, i uticaj unutrašnjosti Selimije ne proizlazi iz slika, ukrasa ili dekorisanja već iz jednostavnosti volumena. Iako džamija navodi građanina Jedrena da oseti moć osmanske države i njenog padišaha, njenu odlučnost, bogatstvo i tehničku veštinu, čim uđe unutra celo to zdanje s magijom svetlosti, koja se probija kroz mnogobrojne prozorčiće i čoveka zaslepljuje, njemu govori o skromnom mestu ljudskog bića na svetu (Pamuk, 2011: 279-280).“

\section{O politici}

Kao intelektualac i humanista, Orhan Pamuk je okupiran i političkim pitanjima o kojima je takođe napisao više eseja. Oni se mogu podeliti na oglede o političkoj situaciji u Turskoj i one u kojima se razmatraju svetski politički fenomeni. Ti tekstovi takođe otkrivaju ovog turskog pisca kao beskompromisnog borca za ljudsko dostojanstvo i slobodu, za slobodu mišljenja i izražavanja, za ravnopravnost ljudi i naroda. Kao što je odan lepoti, književnosti, očuvanju ličnog i nacionalnog identiteta, tako je nepotkupljivo privržen ideji uspostavljanja trajnog civilizacijskog dijaloga između Istoka i Zapada (to su termini koje on, inače, ne voli, smatrajući ih novinarski površnim). Lično sam impresionirana očaravajućim spojem tradicije i modernosti, turskog i svetskog, istočnog i zapadnog u njegovom delu. Sam je to potvrdio rekavši da se „vratio u prošlost sa svojim postmodernističkim formama“. On je neko ko ne predstavlja samo tradiciju, tradicionalnu sufijsku književnost, tradicionalnu formu, tradicionalni način gledanja na stvari, već i neko ko je dobro verziran u onome što se zbiva u zapadnoj književnosti. „Mešam modernizam sa tradicijom što moje delo čini dostupnim, misterioznim i, pretpostavljam, privlačnim za čitaoca (McGaha, 2008: 114).“ 
I kad je o današnjoj Turskoj reč, Orhan Pamuk nastoji da uspostavi onu preko potrebnu nit između prošlosti i sadašnjosti. U Turskoj to nije uvek jednostavno, zato što je sa ukidanjem imperije i uspostavljanjem republike načinjen gotovo hirurški rez između dva sistema. S druge strane, Pamuk nije oduševljen ni gorljivim turskim nacionalistima, ni proevropljanima i modernistima, ni isključivim tradicionalistima, kao što nije oduševljen ni uskogrudim stavom Zapada koji istočni svet gura $u$ fanatizam, nepoverenje i terorizam. To je vidno u eseju Politika potlačenih: „Oni koji danas bezrezervno odobravaju vojne akcije samo da bi demonstrirali američku vojnu moć i da bi 'očitali lekciju' teroristima nekim simboličnim činom, oni koji, kao da igraju video-igru, komotno diskutuju na televizijama o tome šta će bombardovati američki avioni, treba da znaju da će na brzinu i nepromišljeno donete odluke o počinjanju rata raspaliti netrpeljivost prema Zapadu u islamskim zemljama i siromašnim delovima sveta i da će kod miliona ljudi osnažiti osećanja poniženosti i potlačenosti. Ono što hrani teroriste koji pribegavaju tako brutalnim i u istoj meri kreativnim metodama, neviđenim u dosadašnjoj istoriji čovečanstva, nije islam, pa čak ni direktno siromaštvo, već osećanja potlačenosti i poniženja koja kao kancer nagrizaju zemlje Trećeg sveta (Pamuk, 2011 200-201).“

U besedi u čast Artura Milera Orhan Pamuk se posebno dotakao slobode misli rekavši: „Sloboda misli i govora pravo je svih ljudi bez obzira na to koja je nacija u pitanju. Slobode za kojima moderni čovek vapi kao za hlebom i vodom, nacionalna osećanja i duhovni sentimenti ne mogu se ograničavati pod izgovorom nacionalnih interesa. Mnogi narodi izvan zapadnog sveta danas žive život u stidu, život siromašniji od onog koji zaslužuju, ne zato što postoji sloboda misli već zato što je nema. Oni koji zbog ekonomskih teškoća i surovih političkih pritisaka migriraju na Zapad iz tih siromašnih zemalja susreću se tamo sa užasnim rasističkim poniženjima, što nam je svima poznato. Treba da budemo oprezni kad su u pitanju rasizam i poniženje na koje imigranti nailaze u zapadnim zemljama, posebno u Evropi. Treba da smo budni pred onima koji se odluče da ponižavaju imigrante i manjine zbog njihove religije, etničkih korena, zbog nasilja koja čine vlade prema sopstvenim narodima u zemljama koje su napustili. Ali osećati poštovanje prema pravima manjima i njihovoj ljudskosti ne znači tolerisati one, što koristeći svaku vrstu uverenja kao izgovor, atakuju na slobodu misli preko duhovnosti manjina. Neki od nas mogu da razumeju Zapad, neki mogu osećati više poštovanja prema ljudima koji žive na 
Istoku, neki, poput mene, mogu da se trude da čine i jedno i drugo istovremeno, ali ta privrženost i želja za razumevanjem nikada ne bi trebalo da bude ispred poštovanja slobode misli (Pamuk, 2011: 168-169).“

U Turskoj je u prvim decenijama Republike postojala snažna volja za prihvatanjem evropskih institucija i tradicija. Bilo je to vidno u optimizmu generacije Pamukovih roditelja i njihovom načinu života. Pisac je to uočavao prilikom prazničnih porodičnih okupljanja. Ali kako je u poslednje vreme u Turskoj sve više rastao evroskepticizam i ogorčenost zbog nemogućnosti pune evropeizacije i punopravnog članstva u Evropskoj uniji, tako je sve više bio uočljiv gnevni turski nacionalizam. To je sjajno opisano u eseju Istok-Zapad i nacionalizam o praznicima:

„To slepo viđenje 'prosvećenosti' Zapada je nešto nepromišljeno jer unižava i omalovažava tradiciju i okreće leđa istoriji u kojoj živimo. Ali u naivnoj privrženosti evropeizaciji, za nekadašnjim prazničnim ručkovima bilo je nade, čistote i, što je najvažnije, znatiželje svojstvene deci. Evropeizacija se priželjkivala i sa iskrenim žarom su se zanimali kako su oni ${ }^{1}$ postali takvi. Bilo je stvari koje je trebalo naučiti od Zapada. Sva ta duhovna stanja stvarala su određenu atmosferu. Ljutiti i nesrećni starci koji su za ovaj Bajram dremali pred stalno uključenim televizorima, dobrostojeći sredovečni ljudi, istanbulski buržuji koji su prisvojili odviše turskog bogatstva, dovoljno snabdeveni u Parizu i Londonu, svi su uglas proklinjali Evropu i Zapad. Više nema one detinje radoznalosti za to šta je Zapad. Nema više ni sakoa i kravata kao na starim bajramskim ručkovima. Možda je to ispravno, zato što smo za sto godina manje-više naučili šta je to Zapad. Ali suštinski bes dolazi otuda što u međuvremenu nismo uspeli da se evropeizujemo i što znamo da nas Evropa ne želi. Sada svi mrmljaju s gnevom staraca čiji se dečački snovi nisu ostvarili (Pamuk, 2011: 197).“

\section{Zaključak}

Možda je ponajbolju ocenu intelektualnog sveta oličenog u esejima Orhana Pamuka dao Miljenko Jergović, pišući nadahnuti osvrt na delo Druge boje: „Njegova intelektualna platforma postavljena je vrlo visoko, iznad životne sudbine i iznad cijeloga turskog naroda i jezika, ali interesi su mu, vrlo često, identični interesima novinskih kolumnista koje opisu-

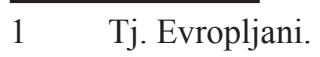


je, te njihove vjerne čitateljske publike. Takav spoj od Orhana Pamuka čini neusporedivoga, velikog pisca.'Druge boje' pokazuju iz kakvoga su svijeta, intimnoga i intelektualnog, proizašli njegovi romani (Jergović, 2012).“

Esejistička proza Orhana Pamuka potvrđuje njegov status rasnog pisca, vrsnog intelektualca i humaniste koji spada u vodeće duhove našeg doba. Esejističko delo ovog književnika neobično je važno za proučavanje njegovog ukupnog književnog opusa, stava prema problemima savremenog sveta, položaja Turske, odnosa prema islamskoj tradiciji i modernizaciji turskog društva, prema umetnosti i književnosti, turskoj i svetskoj literaturi.

\section{Literatura:}

JERGOVIĆ M. (2012). Orhan Pamuk, kolumnist. http://www.jergovic. com/subotnja-matineja/orhan-pamuk-kolumnist/ [10. 4. 2012]

МАГАРАШЕВИЋ М. (2012). Турска йисма. Нови сад. Академска књига.

MARINKOVIĆ M. (2011). Orhan Pamuk o Fjodoru Mihajloviču Dostojevskom, Filološki pregled, XXXVIII, 2011/2, 167-173.

McGAHA M. (2008). Autobiographies of Orhan Pamuk. The Writer in His Novels, Salt Lake City. The University of Utah Press.

PAMUK O. (1999). Öteki Renkler. Seçme Yazılar ve Bir Hikâye. İstanbul. İletişim.

PAMUK O. (2006). Istanbul. Uspomene i grad. Prev. Mirjana Marinković. Beograd. Geopoetika.

PAMUK O. (2007). Babamın Bavulu. İstanbul. İletişim.

PAMUK O. (2010). Manzaradan Parçalar. İstanbul. İletişim.

PAMUK O. (2010a). The Naive and the Sentimental Novelist. Transl. by Nazım Dikbaş. Cambridge, Massachusetts, and London, England. Harvard University Press.

PAMUK O. (2011). Druge boje. Eseji i jedna priča. Prev. Mirjana Marinković. Beograd. Geopoetika. 
Mirjana Marinković

\section{Summary}

\section{ESSAYS OF ORHAN PAMUK}

The paper researches the essays of Orhan Pamuk that have a significant importance for his literary work and his identity as a writer. The essays were written on various occasions and they treat a lot of topics of his personal life, his intellectual, literary and artistic occupations presented in columns and texts written for papers and magazines.

The paper is based on several sources - Other Colors. Essays and a Story, My Father's Suitcase, Istanbul. Memories of a City, The Naive and the Sentimental Novelist, Parts of a Landscape. Pamuk's essayistic works prove that he is really one of the leading intellectuals and writers of our time.

Key words: Orhan Pamuk, essay, literature, art, politics. 